\title{
Frameworks for nurturing and assessing students' statistical thinking in regression modelling
}

\author{
Ken W Li \\ From Practical Social and Industrial Research (PSIR) Symposium 2014 \\ Wanchai, Hong Kong. 5 December 2014
}

\begin{abstract}
Background
One educational objective in any statistics curriculum is to teach students how to think statistically [1]. However, the definition of statistical thinking can be as broad as the thought processes involved in statistical activities or work or as narrow as focusing on the study of variation. To achieve this objective, it is necessary to know what statistical thinking means and how statistical thinking should be taught. In addition, it would be better to assess how well the students' statistical thinking is developed. The aim of the assessment was to provide information to teachers about how to improve pedagogy to support learning [2].
\end{abstract}

\section{Methods}

A test was conducted in a computing laboratory to assess key aspects of the students' statistical thinking in regression modelling. A sample of 23 students studying in the Hong Kong Institute of Vocational Education attempted seven questions on an individual basis, and a set of real-life data with local context was given in the test. Questions 1-2, 3-5 and 6-7 were used to evaluate how much the students understand the given data regarding relations between variables, statistical relations between variables and functional relations between variables, respectively. According to Bishop and Talbot's model of statistical thinking [3], the first two questions are equivalent to the task of reasoning about data, the fourth and the sixth questions are similar to the task of reasoning about results, and the last question is consistent with the task of reasoning about conclusions. A qualitative analysis of students' responses to each of the questions was performed within the frameworks of Jones et al. [4] and Putt et al. [5] to determine which of

Correspondence: kenli@vtc.edu.hk

Department of Information and Communications Technology, Hong Kong Institute of Vocational Education (Tsing Yi), Hong Kong these four levels of statistical thinking, idiosyncratic thinking, transitional thinking, quantitative thinking and analytical thinking, they achieved.

\section{Results}

After the analysis was performed, it was found that a few students demonstrated the ability of idiosyncratic thinking by being able to justify the reasonableness and meaningfulness of data measurement with correct and thorough answers. Among the 23 students, about ten who demonstrated their good knowledge of correlation graphing and proficiency in using Excel graphing tools, displayed the ability of transitional thinking. Nine students showed the ability of quantitative thinking by accomplishing statistical hypothesis testing tasks in which they provided proper formulation of null and alternative hypotheses; correct statistical evidence and decision; and sound reasoning with statistical evidence from Excel output and statistical implications. None of students could deduce the data relation in a practical context, implying that the ability of analytical thinking was deficient.

\section{Conclusions}

The findings of this study alert teachers to the importance of enhancing their students' abilities of idiosyncratic and analytical thinking.

\section{Published: 4 December 2014}

\section{References}

1. American Statistical Association.: Curriculum guidelines for undergraduate programs in statistical science [Internet]., c-2014 [cited 2014 Jun 17]. Available from http://www.amstat.org/education/curriculumguidelines.cfm.

2. Chance BL: Experiences with authentic assessment techniques in an introductory statistics course. J Stat Educ 1997, 5(3):115.

3. Bishop G, Talbot M: Statistical thinking for novice researchers in biological science. Proceedings of the IASE Round Table Conference on Training Researchers in the Use of Statistics; 2000 Granada, Spain: Universidad de Granada; 2001, 215-226.

\section{SpringerOpen ${ }^{\circ}$}

(c) 2014 Li; licensee Springer. This is an Open Access article distributed under the terms of the Creative Commons Attribution License (http://creativecommons.org/licenses/by/4.0), which permits unrestricted use, distribution, and reproduction in any medium, provided the original work is properly credited. 
4. Jones G, Thorton C, Langrall C, Mooney E, Perry B, Putt I: Students' statistical thinking. Proceedings of The Twentieth Annual Meeting, North American Chapter of the International Group for the Psychology of Mathematics Education; 1998 Columbus, OH: ERIC Clearinghouse for Science, Mathematics and Environmental Education; 1998, 371-376.

5. Putt I, Perry B, Jones G, Thornton C, Langrall C, Mooney E: Primary school students' statistical thinking: A comparison of two Australian states. Proceedings of the Twenty-third Annual Conference of the Mathematics Education Research Group of Australasia; 2000 Perth: Mathematics Education Research Group of Australasia; 2000, 519-526.

doi:10.1186/2193-1801-3-S1-05

Cite this article as: Li: Frameworks for nurturing and assessing students' statistical thinking in regression modelling. SpringerPlus 2014 3(Suppl 1):

\section{Submit your manuscript to a SpringerOpen ${ }^{\circ}$ journal and benefit from:}

- Convenient online submission

- Rigorous peer review

- Immediate publication on acceptance

- Open access: articles freely available online

- High visibility within the field

- Retaining the copyright to your article

Submit your next manuscript at $>$ springeropen.com 